\title{
ANOTHER SUMMER CONCENTRATION OF COMMON LOONS
}

by Ronald G. Predy, Conservation Officer, Snow Lake, Manitoba

As an addition to the records of summer flocking of Common Loons reported in the June 1972 Blue Jay $(30: 85-86)$ by $R$. W. Nero, we wish to note the following.

About noon on July 25, 1972, Fire Ranger Russel Bartlett and I were out on patrol on Reed Lake in Grass River Provincial Park, Manitoba. In about the center of the lake, within a square mile area, we encountered a remarkable concentration of about 200 loons. Then, travelling on a bit, we realized that we were surrounded by loons; we estimated 500 birds altogether on the lake. I had never seen a concentration of loons like this before, though on previous patrols in this particular area of Reed Lake I recall always seeing at least a few.
The loons were gathered in pairs, but with only a few appearing to be in the close vicinity of others. No young birds were abserved in the immediate area, but some loons were far away and young birds could have been missed. The birds were spaced fairly evenly throughout the area and there were no compact groupings. The birds were diving occasionally, but mostly they were just swimming around or simply resting. The day was sunny and the lake was calm with a light northeast wind.

As previously pointed out by Nero, most large concentrations of Common Loons in this region have been reported for an area within 50 miles of Flin Flon. It is thus of interest to note that Reed Lake lies just 50 miles east of Flin Flon.

\section{THE PASSENGER PIGEON - ADDENDUM AND ERRATUM}

by C. Stuart Houston, 863 University Drive, Saskatoon

The article on "The Passenger Pigeon in Saskatchewan" (Blue Jay 30:77-83, June 1972) was material gathered to assist Dr. Arlie W. Schorger, Emeritus Professor of Wildlife Ecology at the University of Wisconsin. When he wrote me on November 23, 1971, for assistance concerning a point of history and geography, he was preparing a second, revised edition of his book, The Passenger Pigeon, which first appeared in 1955.

This book was an example of historical ornithology at its best. The ibliography listed well over 2,000 references, including many items Schorger gleaned from newspapers of the 1850's and 1860's. Not surprisingly, however, he was confused by the lifferent "Pine Islands" on the Saskatchewan, and confused Cross Lake (there were actually three lakes by this name between York Factory and Cumberland House) and Ile-a-laCrosse; these accounted for two errors on page 261 of his book. Again, he can be forgiven for assuming that the younger Alexander Henry's Terre Blanche post (in present-day Alberta) was on Henry's Terre Blanche River (in modern Manitoba).

Since Doctor Schorger died on May 26, 1972, before he could complete his revision, it is perhaps best to record the following errors concerning his Manitoba migration records on page 284 of his book: Park River post was not in Manitoba, but in present-day North Dakota, about 43 miles south of the 49th parallel; Pine Island of Henry's observation was not a named locality; the Swan River observation of Daniel Harmon was not a migration date; the A. Henry observation 
of August 31, 1810 at Terre Blanche, was in present Alberta.

Gary W. Seib and Gary Anweiler have both called my attention to a serious error in the caption depicting the University of Saskatchewan, Saskatoon campus, Biology museum specimen on page 80 of the June Blue Jay article. This was stated to be "the only specimen in Saskatchewan," but Seib and Anweiler called to my attention the presence of Passenger Pigeon specimens in the Swift Current Museum and the Saskatchewan Museum of Natural History, Regina.

Mrs. Clarence Wilson, curator of the Swift Current Museum, writes that their specimen, dating from about 1886, was donated in more recent years by Charles Warren. It had been given to his father, George Warren of Swift Current, by Police Chief Jarvis of Bowmanville, Ontario, about 1910.

M. K. Baker, Director of the Saskatchewan Museum of Natural History, wrote to explain the absence of their two Passenger Pigeon specimens from the annual museum accession lists. In fact, these two specimens have not been accessioned and hence no information concerning them is available, except that they are believed to be from Ontario.

\section{NOTES ON A CAPTIVE POOR-WILL IN ALBERTA}

\section{by Loran L. Goulden, Biochemistry, University of Alberta, Edmonton}

The purpose of this article is not to encourage the taking in or capturing of birds that could survive when left alone, but to report on an interesting house guest. On October 27, 1971, Mr. and Mrs. John Hostvedt, who farm near Lindberg, about 165 miles northeast of Edmonton, found by the doorstep of their house, a Poor-will (Phalaenoptilis nuttallii) that appeared to be sluggish. After taking the bird inside and finding that it became active, they released it. Three days later, however, it was back on their doorstep and since it was now cold outdoors and snowing, the Hostvedts decided to let it stay in their home (Lister, 1972).

The only authenticated record of the Poor-will in Alberta is of one collected in the Cypress Hills area of southeastern Alberta in 1945 (Salt and Wilk, 1966) a region about 350 miles south of the Hostvedt farm. The bird normally winters from central California, southern Arizona, and Texas south to central Mexico (Reilly, 1968). According to Godfrey (1966), it breeds from southern interior British Columbia, southern Alberta, northwestern South Dakota, and southwestern Iowa south (on the Pacific Coast from central California to southern Baja Cali- fornia) and through eastern Kansas and central Texas to central Mexico. $\mathrm{He}$ adds that it probably breeds in southwestern Saskatchewan (Calf Creek). The basis for this last statement was provided by a collected specimen (Bard, 1961). A second collection was made in the same area in 1964 (Beck, 1965). Elliott states (1966) that the known range of the Poor-will in Saskatchewan includes areas ranging in climate from very hot and dry, such as the Great Sand Hills and the Frenchman Valley, to relatively cool and humid, like the Cypress Hills.

That the Poor-will "hibernates" during the winter in the northern part of its range has been known for some time. In 1946 Jaeger ('48, '49, '53) found a Poor-will in a torpid state in the Chuckawalla Mountains near the southeast tip of California, midway in the Colorada Desert between Salton Sea and the Colorado River. $\mathrm{He}$ observed it for three years as it came back to the same spot each year. One winter it slept without food for 88 days. The temperature of its body was as low as $64.4^{\circ} \mathrm{F} \quad\left(18^{\circ} \mathrm{C}\right)$, never above $67^{\circ} \mathrm{F}\left(19.4^{\circ} \mathrm{C}\right)$. The normal temperature of an active Poor-will is known to be about $106^{\circ} \mathrm{F}\left(41^{\circ} \mathrm{C}\right)$.

Culbertson (1952) mentions finding 